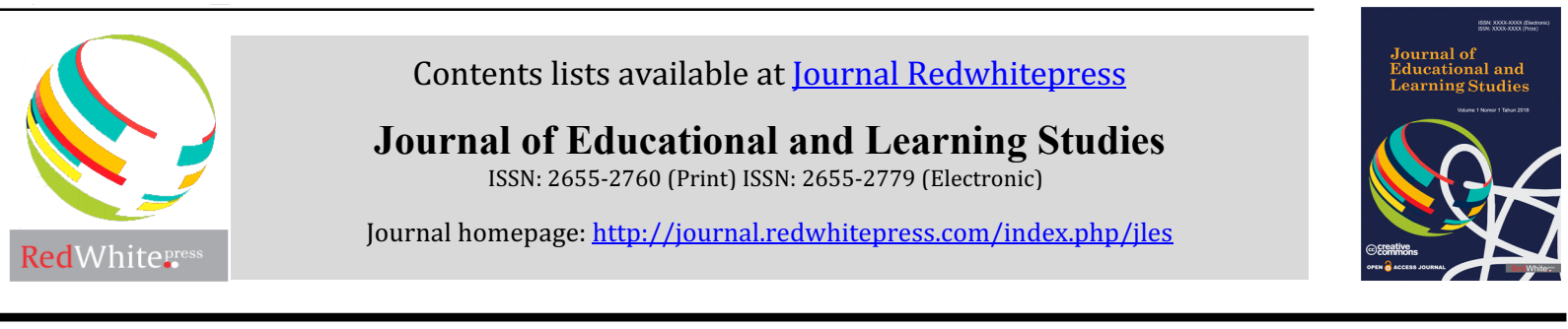

\title{
The Contribution of Self-Concept and Parental Support towards Learning Motivation of The Students who were Expelled from Their Previous Schools
}

\author{
Yogi Sefra Joni ${ }^{1}$, Mudjiran ${ }^{2}$, Yanuar Kiram ${ }^{3}$ \\ ${ }^{123}$ Universitas Negeri Padang, Padang-Indonesia
}

\begin{tabular}{|c|c|}
\hline Article Info & ABSTRACT \\
\hline Article history: & $\begin{array}{l}\text { Underlying this present study was the importance of increasing the learning } \\
\text { motivation of students who were expelled from previous schools. Self-concept }\end{array}$ \\
\hline $\begin{array}{l}\text { Received Mar } 17^{\text {th }}, 2019 \\
\text { Revised Jun } 29^{\text {th }}, 2019 \\
\text { Accepted Sep } 26^{\text {th }}, 2019\end{array}$ & $\begin{array}{l}\text { and parental support were considered as the factors affecting learning } \\
\text { motivation of the students who were expelled from previous schools. The } \\
\text { aimed of this study was to reveal the contribution of self-concept and parental } \\
\text { support towards the learning motivation of the students who were expelled }\end{array}$ \\
\hline Keyword: & quantitative method. The population of the study were the 11th and 12th grade \\
\hline Self-Concept & $\begin{array}{l}\text { students in Sungai Penuh City, which numbered } 2066 \text { in total. The samples of } \\
\text { the study were } 62 \text { students, taken by purposive sampling technique, namely }\end{array}$ \\
\hline Parent Support & students who were expelled from the previous schools. The instrument used \\
\hline Learning Motivation & $\begin{array}{l}\text { was a Likert scale. The research findings showed that self-concept and parental } \\
\text { support respectively and simultaneously had a significant contribution to the } \\
\text { learning motivation of the students who were expelled from their previous } \\
\text { school. }\end{array}$ \\
\hline
\end{tabular}

\section{Corresponding Author:}

Yogi Sefra Joni,

Universitas Negeri Padang, Padang-Indonesia

Email: yogisefrajoni@gmail.com

\section{Introduction}

School is a formal educational institution that has an important role in the efforts of not only realizing the ideals of the students but also developing all their potentials. Developing students' potentials in schools can be realized through the learning process. There are many factors, however, that affect the realization of these efforts. Slameto (2010) explains that the implementation of the learning process in schools is influenced by two major factors, namely internal factors and external factors. The former, which come from within the students themselves, consist of physical factors, psychological factors, and fatigue factors. While the later, which originates from the outside, include family factors, school factors, and community factors. When these factors support learning activities, the students will succeed in learning. Conversely, when these factors do not support and hinder the learning process instead, learning problems will occur.

Imron (2012) suggests one of the factors that can influence student learning processes and outcomes in school is school discipline. Discipline is a condition in which something is in an orderly, orderly, and proper state, and there are no violations, either directly or indirectly. Tu'u (2004) explained that the discipline applied in schools would be very useful in creating a conducive and effective learning atmosphere. The discipline that applies to schools is permanent and binding. Every student is obliged to obey them, and if there is a violator they are usually given sanctions. The sanctions that are usually given to students who often violate the form of 
reprimands and giving advice, making a letter of agreement, calling parents to school until expelled from school.

Based on the phenomenon found in SMAN 2 Sungai Penuh, there were several transfer students from other schools. Some of them were transferred since they were expelled from previous schools for they violated school discipline, including often not going to school without information, engaging in brawls between students, fighting against teachers, carrying out pornographic acts, and being caught smoking and stealing friends' belongings. In the new school, most of the students did not show change, these students still violated school discipline and repeated the mistakes they had made in the previous school. They should be able to take the lessons from their past and not to repeat their mistakes in order to survive in the new school.

In addition, most transfer students who were expelled from their previous schools also had low motivation in learning. Based on the data gotten from Guidance and Counseling teachers, during the school year of 2017-2018, the transfer students who were expelled from previous schools usually did not attend the school, were often late for school, and likely to send fake letters of permission. Moreover, based on the results of interviews with several subject teachers conducted on January 12, 2018, to January 13, 2018 it could be concluded that transfer students who were expelled from school often skipped classes, did not make assignments, did not carry learning equipment, and often daydreamt and liked to isolate themselves from the others. Based on these problems, some of them who liked to violate school discipline and had low motivation to study were forced to be expelled from school.

Bahri, A., \& Corebima (2015) suggested that they can avoid the problems atabove, it is very important to increase student motivation, because motivation is the reason why students want to do learning activities, keep learning, and help to do learning tasks. Students who have high motivation to learn will avoid problems in learning that can harm themselves. Djamarah (2011) explains that in the learning process, motivation is very necessary because students who have no motivation in learning, it will not be possible to carry out learning activities. In line with that, Waruwu (2006) also explained that the role of motivation is very important in the success of the learning process. Students who do not have enough motivation certainly have low interest in learning subject matter, because students will not be compelled to find the information needed and make efforts to deepen the subject matter.

Chen (2009) states that motivation has significant contribution to the success of learning and it is crucial. In line with this, Keklik, I \& Keklik (2012) also state that motivation is very important in studying, as the existance of motivation gives encouragement in students self for following and doing the process of learning. Without motivation, it is hard to understand what is being learnt.

High and low learning motivation can be influenced by several factors. Dimyati \& Mujiono. (2009) explain that the factors influencing learning motivation are: aspirations, students' conditions, learning abilities, students' environmental conditions, elements in learning, and teacher's efforts in teaching students. The aim of this present study was to determine the factors that influence learning motivation of the students who were expelled from school. This study focused on two learning motivation factors, namely students' conditions (self concept) and students' environmental conditions (parental support).

Based on the results of individual counseling done in the second semester of 2017 school year on some students who were expelled from their old schools it was revealed that the students considered themselves as waste and useless. They also felt that they were not cared for by the teachers and were not accepted by the school, which made them feel inferior and prefer to skip classes and be lazy to go to school. Besides, their parents also tended to scold them and bring up the problems causing them to be expelled.

Guidance and Counseling Services play an important role in an effort to deal with the problems of the low self-concept of students and the support provided by the parents which can affect the learning motivation of students who were expelled from previous schools. Guidance and Counseling is an integral part of the education process. Juniyarti, M. E., Prayitno \& Marjohan (2018) Guidance and Counseling is seen as an educational process for learning to have positive thoughts to increase student learning motivation. Various types of services and supporting activities carried out by Guidance and Counseling teachers can be solutions to the phenomenon described above. In order to realize the implementation of the services and supporting activities in the learning process, it is needed to develop service programs, materials, and media used in delivering service material, so the right and useful role of Guidance and Counseling for students can be achieved.

The objectives of this study were: 1) to describe the self-concept description of the students who were expelled from previous school, 2) to describe parents' support for the students, 3) to describe learning motivation of the students, 4) to find out whether there was a contribution of self-concept to the learning student motivation of the students, 5) to find out whether there was a contribution of parental support on learning motivation of the students, 6) to find out whether there was a contribution of self-concept and parental support on learning motivation of the students. 


\section{Method}

This study used a descriptive correlation-quantitative method. The population of the study were the 11th and 12 grade students of Sungai Penuh city, which numbered 2666 in total. 62 students were taken as the samples of the study by using purposive sampling technique, namely: 1) all students in the 11th and 12th grade who were expelled from their old schools for violating school discipline; 2) students who were expelled from school, then moved and continued their education in other schools that were still registered in the second semester of the 2017-2018 school year. The instrument used was a Likert model scale. Data were analyzed by descriptive statistics, simple regression, and multiple regression.

\section{Results and Discussions}

\section{Description of Data}

1. Description Description of Self Concept Data

Overall self-concept data shows that students have a moderate self-concept that is equal to $67.36 \%$. The results of data analysis on each indicator show that: the physical aspect is in the high category that is $76.45 \%$, the social aspect is in the high category that is $73.50 \%$, the cognitive aspect is in the medium category that is $66.13 \%$, the emotional aspect is in the medium category that is equal to $62.13 \%$, and moral aspects are in the medium category that is equal to $56.86 \%$.

2. Description of Parental Support Data

In general, from the parental support data of all indicators, parental support is in the high category that is 76.75.\%. This can be seen from the results of data analysis on each indicator, among others: the informative support aspect is in the high category that is $82.20 \%$, the instrumental support aspect is in the high category that is $81.83 \%$, the award support aspect is in the high category that is equal to $74.64 \%$, and aspects of emotional support are in the high category that is equal to $72.86 \%$.

3. Description of Student Learning Motivation Data Student

Learning motivation data shows the learning motivation of students who have been excluded from school is in the medium category that is equal to $60.48 \%$. This can be seen from the results of data analysis on each indicator, among others: aspects that are not easy to release what they believe are in the medium category that is equal to $66.26 \%$, resilient aspects facing learning difficulties are in the medium category that is equal to $64.60 \%$, aspects show interest high learning is in the medium category that is equal to $60.56 \%$, the aspect of independent work is in the medium category that is equal to $54.09 \%$, and the diligent aspect facing the task is in the moderate category that is equal to $53.71 \%$.

Testing Requirements Analysis

Test requirements analysis performed on the data of this study is the normality test, linearity test, and multicollinearity test. Hypothesis testing in this study was conducted with a parametric statistical formula, namely simple regression and multiple regression data analysis techniques.

Normality Test

Table 1. Normality Test Results Self Concept Variables, Parental Support and learning Motivation

\begin{tabular}{|c|c|c|c|}
\hline Variable & Asymp. Sig. & Significance of & Information \\
\hline Self-Concept $\left(\mathrm{X}_{1)}\right.$ & 0.128 & \multirow{3}{*}{0.05} & Normal \\
\hline Parental Support $\left(\mathrm{X}_{2}\right)$ & 0.060 & & Normal \\
\hline Learning Motivation (Y) & 0.284 & & Normal \\
\hline
\end{tabular}

The results of the normality test calculation in Table 1 show that all three variables have scores Asymp. Sig. greater than predetermined significant (0.05). That is, data from the three variables are normally distributed. This shows that one of the requirements for regression analysis has been fulfilled. Linearity Test

Table 2. Linearity Test Results Self-Concept $\left(\mathrm{X}_{1}\right)$, Parental Support $\left(\mathrm{X}_{2}\right)$, Against Student Learning Motivation (Y)

\begin{tabular}{ccccc} 
No & Variable & F & Significance & Information \\
\hline 1 & $\mathrm{X}_{1} \mathrm{Y}$ & 66,880 & 0,000 & Linear \\
\hline 2 & $\mathrm{X}_{2} \mathrm{Y}$ & 30,654 & 0,000 & Linear \\
\hline
\end{tabular}


Test Results linearity in table 2, shows that the data on the self-concept variable $\left(\mathrm{X}_{1}\right)$ with $\mathrm{F}_{\text {ount }} 66,880$ and the parent support variable $\left(\mathrm{X}_{2}\right)$ with $\mathrm{F}_{\text {ount }} 30,654$ significance values known $0,000<0.05$, because values linearity less than 0.05 can it was concluded that the data for each variable $(\mathrm{X})$ is linear. Multicollinearity Test

Table 3. Multicollinearity Test Results between Self-Concept $\left(\mathrm{X}_{1}\right)$ and Parental Support $\left(\mathrm{X}_{2}\right)$

\begin{tabular}{ccc}
\hline Variable & Tolerance & VIF \\
\hline (Constant) & & \\
\hline $\mathrm{X}_{1}$ & 0.852 & 1,173 \\
\hline $\mathrm{X}_{2}$ & 0.852 & 1,173
\end{tabular}

Based on Table 3, which shows that the value $V I F$ of self-concept is 1,173 and value $V I F$ of parental support 1,173. Based on the above table, thus both VIFs are smaller than 10. This means that there is no multicollinearity between self-concept and parental support.

\section{Research Hypothesis Testing}

\section{The First Hypothesis}

Based on a simple regression analysis of self-concept towards student motivation who were excluded from previous schools, the results showed that the determination coefficient value of R Square (R2) was 0.584, which means that $58.4 \%$ of the contribution of self-concept to the learning motivation of the students who were expelled from previous schools, while $41.6 \%$ was influenced by other factors. Furthermore, a simple regression equation analysis was carried out and the results showed that $t$ count 9,175 with a significance value of $0,000<0,05$, then $\mathrm{H} 0$ was rejected and $\mathrm{Ha}$ was accepted. This finding means that $\mathrm{Ha}$ was accepted, that self-concept had a contribution to the learning motivation of students who were expelled from previous schools.

2. The Second Hypothesis

Based on a simple regression analysis of parental support towards learning motivation of students who were expelled from school, the results of the determination coefficient value of R Square (R2) are 0.313, which means that $31.3 \%$ of the contribution of parental support towards learning motivation of the students who were expelled from previous schools, whereas $68.7 \%$ were influenced by other factors. Furthermore, a simple regression equation analysis was carried out and the results showed that $t$ count 5.229 with a significance value of $0.000<0.05$, then $\mathrm{H} 0$ was rejected and $\mathrm{Ha}$ was accepted. This finding means that $\mathrm{Ha}$ was accepted, that parental support had a contribution to the learning motivation of students who were expelled from previous schools.

3. The Third Hypothesis

Based on multiple regression analysis of self-concept and parental support for learning motivation of the students who were expelled from previous schools, the results showed that the determination coefficient value of R Square (R2) was 0.667 , which means the contribution of self-concept and parental support to the learning motivation of students who were expelled from previous schools was $66.7 \%$, while $33.3 \%$ was influenced by other factors. Furthermore, a multiple regression equation analysis was carried out and the results showed t count X1 7.914 with a significance value of $0,000<0.05$, and $\mathrm{t}$ count X2 3,830 with a significance value of $0,000<0,005$, then $\mathrm{H} 0$ was rejected and $\mathrm{Ha}$ was accepted. This finding means Ha was accepted, that self-concept and parental support had a shared contribution to the learning motivation of students who were expelled from previous schools.

\section{Discussion \\ Self-Concept}

The results showed that overall self-concept of the students who were expelled from previous schools was in the moderate category. From these results, it could be interpreted that the self-concept of students who were expelled from school was not yet fully high (positive). There still were students who had a low selfconcept (negative). Cokley, K., \& Patel (2007) explains that self-concept as the looking glass self, in which through observation toward themselves, students will be able to picture and judge themselves. Self-Concept is one of many important factors affecting students' behavior in studying. When students regard themselves as diligent and dicipline students in studying, they will have positive self-concept. Positive self-concept will make them attempted to follow the learning well, so they will get good achievement. 
Marimbun, M., Syahniar, \& Ahmad (2017) explain that students who have negative self-concept often view the world with excessive pessimism, respond to conditions unfavorably and do not like others' potentials. In line with that, Dianto, M., Gistituati, N. \& Mudjiran (2015) reveal that if a person's self-concept is not well developed, then many adolescents become uncontrolled in behaving, unhappy with themselves, and have an uncontrolled attitude.

\section{Parental Support}

The results showed that overall parental support for students who were expelled from school was in the high category. From these results, it could be interpreted that parental support for students who were expelled from school was good. The high level of parental support for children's education was because parents cared and were responsible for their children's education so that later they would have bright futures. According to Slameto (2010), encouragement and attention from parents are needed in student learning. Sarafino, E. P., \& Smith (2011) Each student should be given full encouragement and support from each family member. If students have experienced saturation in school, parents must support their children.

Slameto (2010) explains that parents who do not care with their children's education, such as being unconcerned, not to care with the children's need, not to organize the children's learning time, etc., yield unsuccessful learning achievement of the children.

\section{Learning Motivation}

The results of the data analysis showed that overall the learning motivation of students who had been excluded from school was in the moderate category. From these results, it could be said that students who were expelled from previous school had low learning motivation. High and low learning motivation could be influenced by both within and outside the students. In learning activities, motivation was very necessary, because students who had low motivation in learning, would not be possible to do learning activities.

Syah (2012) explains the decreased motivation to learn in students will cause individuals less eager to follow the learning process. Students who are lazy to learn will affect learning motivation and learning achievement. However, if students do not reduce unnecessary actions, then this will disturb the mind and concentration to learn.

The Contribution of Self-Concept towards Learning Motivation of the Students who were Expelled from Their Previous Schools

The results of this study proved that self-concept had a significant contribution towards the learning motivation of students who were expelled from previous schools. This finding was obtained based on the results of data analysis which showed that the contribution of self-concept to learning motivation was $58.4 \%$. It meant that the higher the student's self-concept, the higher the learning motivation of students would be, and vice versa.

The results of this study are supported by several results including the research conducted by Putri, S. R., Syahniar \& Alizamar (2017) revealed that self-concept contributes significantly to student motivation. The higher the self-concept, the higher the student's motivation to learn. Furthermore, Saragi, M. P. D., Iswari, M. \& Mudjiran (2016) research also revealed that self-concept contributes to students' learning motivation by $24.2 \%$. That is, the higher the contribution of students' self-concepts, the higher the student's motivation to learn. Conversely, if self-concept is negative, it will result in students' motivation to learn also getting lower.

Self-concept related to academics is one of the factors that influence motivation to learn because selfconcept as intrinsic motivation greatly determines the behavior of every individual. Sanchez, F.J.P. \& Roda (2003) explains the self-concept related to academics to be one of the factors that influence motivation to learn because self-concept as intrinsic motivation is very determining the behavior of each individual. Putri, S. R., Syahniar \& Alizamar (2017) explained that self-concept has a significant role in determining students' learning motivation. With the contribution of self-concept to students' learning motivation, it shows that a positive selfconcept is needed to enable students to be able to better understand their learning with knowledge, expectations, and judgments about themselves.

The Contribution of Parental Support towards Learning Motivation of the Students who were Expelled from Their Previous Schools.

The results of this study proved that parental support had a significant contribution to the learning motivation of students who were expelled from school. This finding was obtained based on the results of data analysis which showed that the contribution of parental support to learning motivation was $31.3 \%$. It meant that the higher the parental support, the higher the learning motivation of students would be, and vice versa.

Several research results reveal the importance of parental support for student motivation. Dwijia (2008) research results revealed that the support of parents of students is in the high category, by having high support, 
students become eager to learn because they get full support from parents. The results of Ronaldi (2013) research revealed that high parental support is very useful for increasing student enthusiasm for learning.

Maslihah (2011) explains that with the support of parents, in particular, it will provide physical and psychological comfort for their children since their children will feel loved and cared for by their parents. Moreover, students who have problems in which they failed and are expelled from school, they certainly need high support from their parents so that they can accept themselves well, be able to rise up, and are encouraged to get good achievements in the new school. According to Jahja (2011) the support of parents in giving encouragement and motivation, it can help the students to build their confidence, foster high enthusiasm, and make students want to do learning activities well and controlled.

The Contribution of Self-Concept and Parental Support towards Learning Motivation of The Students who were Expelled from Their Previous Schools

The results showed that self-concept and parental support simultanously had a significant contribution to the learning motivation of students who were expelled from school. This finding was obtained based on a series of data analysis which showed that the contribution of self-concept and parental support to students' learning motivation was $66.7 \%$. It meant that self-concept and parental support were factors related to learning motivation of the students who were expelled from their previous schools. The results of this study are supported by research conducted by Saragi, M. P. D., Iswari, M. \& Mudjiran (2016) namely that there is a significant relationship between self-concept and parental support together with student learning motivation. The higher the self-concept and parental support received by students, the higher the motivation of student learning, and vice versa if the self-concept and parental support are low, then student motivation will also below.

The results of the study showed that the learning motivation of students who were expelled from previous schools was still classified as moderate. The high and low of students 'learning motivation is influenced by students' self-concept and parental support given to the students. This should be a full concern for the teacher, especially the Guidance and Counceling Teachers to be able to increase the learning motivation of the students. If this problem is not addressed immediately, it will lead to learning problems, and even worse it will likely cause students to be lazy at school and so they prefer to quit or drop out of the school.

In addition, parents also had a very important role to play in increasing the learning motivation of students who were expelled from their old schools. Fully support from parents was needed by the students since they had problems in which they failed and were expelled from school before, they certainly needed high support from their parents in order to be able to move on and be encouraged to get good achievements in the new school. Therefore, it was important for parents to collaborate with the school, especially Guidence and Counseling teachers to help the students increase their learning motivation.

\section{Conclusions}

Based on the findings and discussion of the results of the study, the following conclusions could be made: 1) the average self-concept of students who were expelled from their previous schools was moderate 2) the average of parents' support towards the students who were expelled from the previous schools was high, 3) the average of learning motivation of the students who were expelled from previous schools was moderate, 4) the concept of self contributes to the learning motivation of students who were expelled from previous schools was $58.4 \%, 5)$ the contribution of parental supports towards learning motivation of the students who were expelled from previous schools was $31.3 \%, 6$ ) self-concept and parental support contributed simultaneously to students' learning motivation which was equal to $66.7 \%$.

\section{References}

Bahri, A., \& Corebima, A. D. 2015. "The Contribution of Learning Motivation and Metacognitive Skill on Cognitive Learning Outcome of Students within Different Learning Strategies." Journal of Baltic Science Education 14(4):487-500.

Chen, Y. 2009. "The Effect of English Popular Songs on Learning Motivation and Learning Performance." An Interdisciplinary Journal 56(1):13-28.

Cokley, K., \& Patel, N. 2007. "A Psychometric Investigation of The Academic Self-Concept of Asian American College Students. Educational and Psychological Measurement." 67(1):88-99.

Dianto, M., Gistituati, N., \&. Mudjiran. 2015. "Kontribusi Dukungan Sosial Dan Konsep Diri Terhadap Motivasi Berprestasi Siswa Di SMP Negeri Kecamatan Batang Kapas Pesisir Selatan." E-Journal Konselor 
$4(1): 19-25$.

Dimyati \& Mujiono. 2009. "Belajar Dan Pembelajaran." Jakarta: Rineka Cipta.

Djamarah, S. B. 2011. "Psikologi Belajar." Jakarta: Rineka Cipta.

Dwijia, I. W. 2008. "Hubungan Antara Konsep Diri, Motivasi Berprestasi Dan Perhatian Orangtua Dengan Hasil Belajar Sosiologi Pada Siswa Kelas XI SMA Unggulan Di Kota Amlapura." Bali: PPs UNDIKSA.

Imron, A. 2012. "Manejemen Peserta Didik Berbasis Sekolah." Jakarta: Bumi Aksara.

Jahja, Y. 2011. "Psikologi Perkembangan." Jakarta: Kencana Prenada Media.

Juniyarti, M. E., Prayitno, \&. Marjohan. 2018. "Content Mastery Service: A Help In Related Consulting Problems Student Learning Activities." International Journal of Research in Counseling and Education 1(3):43-46.

Keklik, I \& Keklik, D. E. 2012. "Examination of High School Student's Motivation and Learning Strategy." Journal of Education 42(1):238-49.

Marimbun, M., Syahniar, \& Ahmad, R. 2017. "Kontribusi Konsep Diri Dan Kematangan Emosi Terhadap Penyesuaian Diri Siswa Dan Implikasinya Dalam Bimbingan Dan Konseling." Jurnal Bimbingan Dan Konseling 6(2):165-75.

Maslihah, S. 2011. "Studi Tentang Hubungan Dukungan Sosial, Penyesuaian Sosial Di Lingkungan Sekolah Dan Prestasi Akademik Siswa SMPIT Assyfa Boarding School Subang Jawa Barat. Universitas Pendidikan Indonesia Bandung." Jurnal Psikologi 10(2):103-14.

Putri, S. R., Syahniar, \&. Alizamar. 2017. "Kontribusi Tingkat Penerimaan Oleh Teman Sebaya Dan Konsep Diri Terhadap Motivasi Belajar Peserta Didik Di SMK Nusatama Padang Serta Implikasinya Dalam Program Bimbingan Dan Konseling." Jurnal Bimbingan Dan Konseling 6(2):223-34.

Ronaldi, R. 2013. "Pengaruh Dukungan Orangtua Dan Kemandirian Belajar Terhadap Hasil Belajar Ekonomi Siswa Siswa Kelas XI IPS SMAN 6 Padang." Jurnal Pendidikan Ekonomi 2(2).

Sanchez, F.J.P. \& Roda, M. D. S. 2003. "Relationships between Self-Concept and Academic Achievement in Primary Students." Electronic Journal of Research in Educational Psychology and Psychopedagogy 1(1).

Sarafino, E. P., \& Smith, T. W. 2011. "Health Psychology: Biopsychosocial Interactions." Hoboken: Jhon Willey \& Sons, Inc.

Saragi, M. P. D., Iswari, M., \&. Mudjiran. 2016. "Kontribusi Konsep Diri Dan Dukungan Orangtua Terhadap Motivasi Belajar Siswa Dan Implikasinya Dalam Pelayanan Bimbingan Dan Konseling." Jurnal Bimbingan Dan Konseling 5(1):1-14.

Slameto. 2010. "Belajar Dan Faktor Yang Mempengaruhinya." Jakarta: Rineka Cipta.

Syah, M. 2012. "Psikologi Belajar." Jakarta: Raja Grafindo Persada.

Tu'u, T. 2004. "Peran Dan Disiplin Pada Prilaku Dan Prestasi Siswa." Jakarta: Grasindo.

Waruwu, F. E. 2006. "Belajar Dan Motivasi: Bagaimana Mengembangkan Motivasi Internal." Jurnal Provitae 2(2):21-24. 